\title{
Karsinoma sel skuamosa penis
}

\author{
Gangga Mahatma ${ }^{1}$, Irza Wahid ${ }^{2}$ \\ 1. Program Studi Pendidikan Dokter Spesialis, Fakultas Kedokteran, Universitas Andalas; 2. \\ Subbagian Hematologi Onkologi Medik Bagian Ilmu Penyakit Dalam, Fakultas Kedokteran, \\ Universitas Andalas/RSUP dr. M. Djamil Padang
}

Korespondensi: Gangga Mahatma; email: ganggamahatma@gmail.com

\begin{abstract}
Abstrak
Karsinoma sel skuamosa penis merupakan keganasan yang jarang yang mewakili 0,4-0,6\% dari semua keganasan pada pria di Amerika Serikat dan Eropa. Di Indonesia, di RS Sardjito pada tahun 2006-2013 didapatkan insiden sejumlah 35 kasus dengan usia rata-rata $56 \pm 14,4$ tahun. Karsinoma penis sering muncul dengan tampilan klinis adanya lesi yang terlihat dan teraba pada penis, bisa disertai nyeri, adanya sekret, perdarahan, atau bau busuk apabila pengobatan ditunda. Tujuan: Melaporkan kasus karsinoma sel skuamosa penis. Kasus: Dilaporkan kasus laki-laki 58 tahun dengan benjolan dan tukak yang semakin membesar di penis dengan hasil biopsi jaringan Squamous Cell Carcinoma Penis, Keratinized, Well to Moderately Differentiated. Pada pasien dilakukan total penectomy dan perineostomy. Tiga bulan kemudian pasien kembali datang dengan benjolan di lipat paha kanan hingga skrotum kanan yang semakin membesar. CT scan abdomen dengan kontras menunjukkan massa di inguinal kanan meluas sampai ke skrotum kanan dan kiri. Pasien didiagnosis dengan Squamous Cell Carcinoma Penis Stadium IV (T3N3M0) post total penectomy dan perineostomy. Metastasis kelenjar getah bening inguinal pada pasien ini ditatalaksana dengan kemoterapi regimen Cisplatin-5FU. Simpulan: Telah dilakukan dua siklus kemoterapi dengan interval 3 minggu dan hasil menunjukkan adanya respon di mana ukuran benjolan mulai mengecil.
\end{abstract}

Kata kunci: karsinoma sel skuamosa; penis; kemoterapi

\section{Abstract}

Penile squamous cell carcinoma is a rare malignancy representing $0.4-0.6 \%$ of all malignancies in the United States and Europe. In Indonesia, Sardjito Hospital reported 35 cases in year 2006-2013 with average age of $56 \pm 14.4$ years. Penile carcinoma most often present with clinical appearance of visible and palpable lesions on the penis, may be accompanied with pain, secretions, bleeding, or foul odor if patient delays treatment. Objective: Reporting case of penile squamous cell carcinoma. Case: 58 -yearold man came with lumps and ulcers that are increasing in size at the penis with biopsy result Squamous Cell Carcinoma Penis, Keratinized, Well to Moderately Differentiated. Patient undergoes total penectomy and perineostomy. Three months later, patient came back with lumps in the groin of the right thigh that expand to right scrotum. Abdominal CT Scan with contrast showed mass at the right inguinal that spread to the right and left scrotum. Patient was diagnosed with Penile Squamous Cell Carcinoma Stage IV (T3N3MO) post-total penectomy and perineostomy. Inguinal lymph node metastasis in this patient was managed with chemotherapy regimen Cisplatin-5FU. Conclusion: Two cycles of chemotherapy with intervals of 3 weeks gave good response where the size of the lump begins to shrink.

Keywords: squamous cell carcinoma; penile; chemotherapy 


\section{PENDAHULUAN}

Karsinoma sel skuamosa penis merupakan keganasan yang jarang yang berasal dari sel epitel di preputium bagian dalam atau glans penis. ${ }^{1,2}$ Insidennya yang jarang di seluruh dunia membuatnya sulit untuk dilakukan penelitian dan uji klinis agar dapat dibuat standar dalam penatalaksanaan keganasan ini. $^{3}$

Karsinoma sel skuamosa penis mewakili 0,4-0,6\% dari semua keganasan pada pria di Amerika Serikat dan Eropa. ${ }^{4,5}$ Pada tahun 2018, perkiraan jumlah kasus baru keganasan pada penis dan genitalia pria lainnya sebanyak 2.320 kasus, dengan kematian mencapai $380 .^{2}$ Insiden meningkat hingga $10 \%$ pada pria di negara berkembang seperti di Asia, Afrika, dan Amerika Selatan. Secara global diperkirakan jumlah insiden keganasan pada penis mencapai 26.000 per tahun. ${ }^{4}$ Data di Indonesia pada tahun 2006-2013 di RS Sardjito didapatkan insiden sejumlah 35 kasus dengan usia rata-rata $56 \pm 14,4$ tahun. ${ }^{6}$

Usia yang paling sering menderita keganasan ini adalah 50 sampai 70 tahun, dengan angka ketahanan hidup 5 tahun sekitar 50\% (lebih dari 85\% pasien dengan kelenjar getah bening negatif dan 29\%$40 \%$ positif, di mana angka ketahanan terendah adalah $0 \%$ pada pasien dengan keterlibatan kelenjar getah bening pelvis). ${ }^{4}$

Beberapa faktor risiko yang dapat meningkatkan kejadian karsinoma penis antara lain: 1) Tidak di-sirkumsisi dan fimosis, sirkumsisi usia dini memberi efek proteksi terhadap karsinoma penis, sedangkan pria dengan fimosis akan meningkatkan terjadinya karsinoma penis sebanyak $25 \%$ sampai dengan $60 \%$; 2 ) Balanitis; 3) Infeksi HPV, ditemukan pada $20 \%$ sampai dengan $50 \%$ karsinoma penis, yaitu dengan HPV tipe 16 dan tipe 18; 4) Merokok, risiko kanker penis pada pria yang merokok meningkat tiga sampai empat setengah kali lipat; 5) Liken sklerosus, berpotensi menjadi karsinoma sebanyak $2 \%$ sampai dengan $9 \%$; 6) Usia, rata-rata usia penderita kanker penis yaitu usia 68 tahun, dimana risiko mulai meningkat setelah usia 50 tahun; 7) Fotokemoterapi Psoralen UV-A (PUVA), terapi PUVA pada penderita psoriasis meningkatkan risiko karsinoma penis dibandingkan populasi umum; 8) Trauma penis; 9) Infeksi HIV; 10) Status sosioekonomi, karsinoma penis memiliki hubungan yang signifikan dengan daerah yang miskin di Amerika Serikat..,7

Tampilan paling sering pada karsinoma penis adalah adanya lesi yang terlihat dan teraba pada penis, yang juga disertai nyeri, adanya sekret, perdarahan, atau bau yang busuk apabila pasien menunda pengobatan. Lesi tersebut dapat berupa nodul atau ulkus dan dapat dikaburkan oleh fimosis. Pasien dapat memiliki tanda penyakit yang lebih lanjut, seperti nodul yang teraba dengan gejala konstitusional. ${ }^{2}$ Keganasan pada penis $95 \%$ berasal dari sel epitel skuamosa dan kemudian dikelompokkan menjadi Squamous Cell Carcinoma (SCC) atau Penile Intraepithelial Neoplasia (PIN). Penile Intraepithelial 
Neoplasia adalah suatu kondisi premaligna yang berisiko tinggi berkembang menjadi SCC. ${ }^{1}$

Pemeriksaan fisik meliputi palpasi pada penis dan region inguinal. Pemeriksaan USG atau MRI dengan ereksi buatan dapat memberikan informasi mengenai infiltrasi korpora. Karsinoma penis sering kali jelas secara klinis namun dapat tersembunyi di bawah fimosis. ${ }^{2}$

Penatalaksanaan diagnostik dengan kelenjar getah bening inguinal yang normal harus diiringi dengan faktor risiko patologi termasuk invasi limfa-vaskuler, stadium, dan derajat. Kelenjar getah bening inguinal yang membesar menunjukkan kemungkinan adanya metastasis. Pemeriksaan fisik harus melihat jumlah kelenjar dan apakah pembesaran terfiksasi atau mobil. Staging untuk kelenjar pelvis dan penyakit sistemik harus dilakukan dengan CT abdominopelvis dan rontgen thoraks atau $\mathrm{CT} .^{2}$

Klasifikasi kanker penis menggunakan klasifikasi dari The American Joint Committee on Cancer (AJCC) TNM (tumor, nodus, dan metastasis) Staging System. Klasifikasi terbaru edisi delapan dipublikasikan pada tahun 2017. Klasifikasi ini diperkenalkan pertama kali pada tahun 1968 dan selalu direvisi pada tahun 1978, 1987, 2002, dan 2010. Pada tahun 2010, AJCC membuat perbedaan yang jelas antara staging klinis dan patologis sementara menghapuskan perbedaan metastasis ke kelenjar getah bening (KGB) superfisial dan kelenjar getah bening dalam. Edisi kedelapan dari AJCC staging system menyertakan perubahan definisi tumor primer $(T)$, termasuk di dalamnya: 1 ) Perluasan definisi Ta dengan memasukkan non-invasive localized squamous carcinoma, 2) Menjelaskan T1 berdasarkan lokasi tumor pada penis (glans, foreskin, shaft) dan mendefinisikan perluasan pada tiap lokasi, 3) Menambahkan perluasan ke perineural sebagai indikator prognosis untuk membedakan T1b dari T1a, 4) Memasukkan perluasan korpus spongiosum dalam definisi T2, 5) memasukkan perluasan corpora cavernosum dalam definisi T3. Sebagai tambahan, edisi kedelapan ini memasukkan perubahan definisi pembesaran kelenjar getah bening, definisi pN1 adalah penyebaran ke kelenjar getah bening inguinal unilateral $\leq 2$ tanpa perluasan ke ekstranodal dan pN2 didefinisikan penyebaran kelenjar getah bening inguinal unilateral $\geq 3$ atau penyebaran kelenjar getah bening bilateral. Selanjutnya, stadium II dipecah menjadi IIA dan IIB.

Tidak ada tumor marker untuk kanker penis. Antigen SCC meningkat pada kurang dari $25 \%$ dan tidak memprediksi metastasis namun kemungkinan memprediksi ketahanan bebas penyakit pada pasien dengan kelenjar limfa positif. ${ }^{1}$

Penatalaksanaan untuk tumor primer dilakukan dengan tujuan pengangkatan tumor secara komplit dengan sebanyak mungkin organ yang dipertahankan sedangkan radikalitas pengobatan tetap tidak dikurangi. Pada penyakit yang telah bermetastasis, kemoterapi adjuvan 
meningkatkan angka ketahanan. ${ }^{8}$

\section{LAPORAN KASUS}

Seorang laki-laki berusia 58 tahun datang dengan keluhan utama benjolan di penis yang semakin lama semakin membesar dan disertai tukak sejak 3 bulan sebelumnya. Pasien tidak mengeluhkan demam, penurunan nafsu makan atau penurunan berat badan. Pasien sudah dikenal menderita kanker penis sejak 1,5 tahun yang lalu. Benjolan awalnya hanya satu buah sebesar buah baju, namun kemudian muncul benjolan lain di dekatnya menjadi tiga buah. Benjolan lalu semakin besar, hingga menjadi pecah dan luka bernanah. Tidak ada riwayat trauma atau kutil sebelumnya pada penis. Pasien di-sirkumsisi pada usia 12 tahun, berasal dari keluarga dengan sosio-ekonomi kurang dan merupakan seorang perokok berat dengan Indeks Brinkman 608. Pada pemeriksaan vital sign dan pemeriksaan fisik umum didapatkan hasil dalam batas normal. Pada genitalia tampak massa bernodul dan berkeropeng pada penis, ukuran $10 \times 8 \times 2 \mathrm{~cm}$. Massa teraba padat, keras dan terfiksasi. Tidak ditemukan pembesaran kelenjar getah bening (KGB) pada daerah inguinal atau benjolan pada daerah lainnya.

Pada pasien dilakukan pemeriksaan biopsi insisi dan diperoleh hasil mikroskopik tampak potongan-potongan jaringan penis permukaan dilapisi oleh epitel berlapis gepeng yang mengalami proliferasi sel-sel dengan inti besar, pleomorfik, vesikuler, kromatin kasar, anak inti nyata, mitosis atipik dapat ditemukan. Sel-sel ini tersusun membentuk lembaran solid infiltratif ke dalam stroma, tampak adanya mutiara tanduk, sebaran sel-sel limfosit dan leukosit PMN sekitar tumor dengan kesan Squamous Cell Carcinoma Penis, Keratinized, Well to Moderately Differentiated. Dari pemeriksaan rontgen torak tidak ditemukan metastasis, dan MRI Abdomen-Pelvis tidak ditemukan kelainan. Pasien kemudian menjalani total penectomy dan perineostomy, serta dijadwalkan untuk kontrol teratur ke poliklinik.

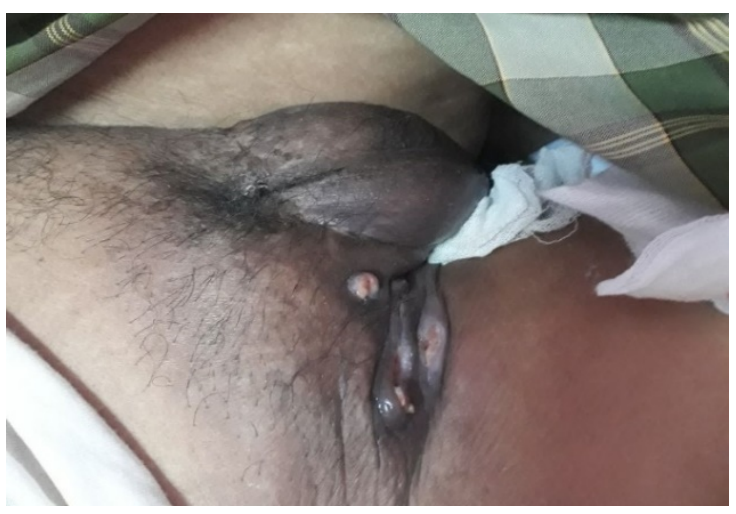

Gambar 1. Tampak penis telah diangkat, benjolan di inguinal kanan dengan tukak di atasnya.

Sembilan bulan kemudian pasien baru kontrol kembali dengan keluhan benjolan di lipat paha kanan sejak 3 bulan sebelum masuk rumah sakit. Benjolan semakin lama semakin besar dan kadang disertai nyeri. Benjolan juga disertai tukak yang bernanah dan berbau di atasnya. Benjolan di bagian tubuh yang lain tidak ada. Pasien juga mengeluhkan nafsu makan yang menurun dan lemah letih sejak 2 bulan yang lalu. Penurunan berat badan sekitar $5 \mathrm{~kg}$ sejak 2 bulan ini. 


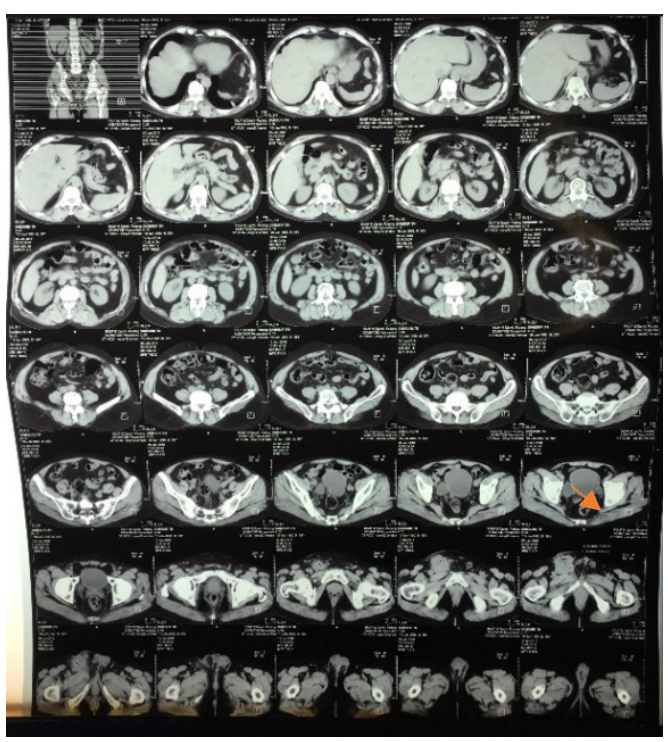

Gambar 2. Tanda panah pada foto CT Scan Abdomen menunjukkan adanya massa di inguinal hingga skrotum.

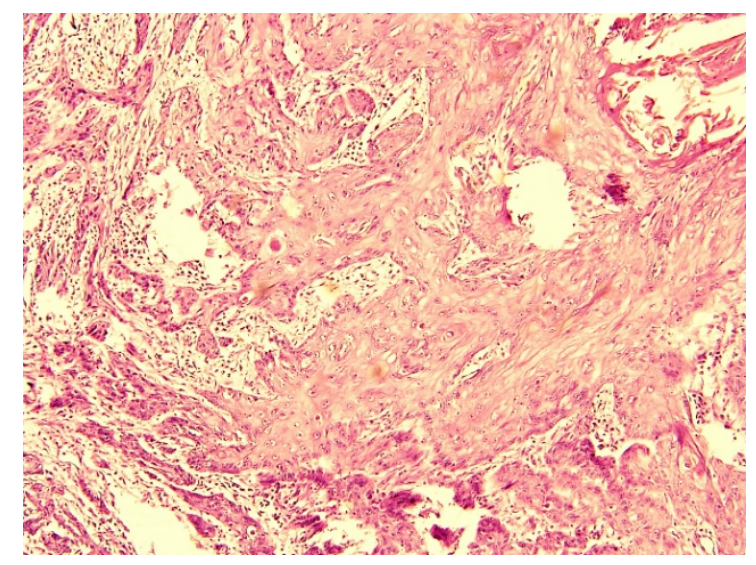

Gambar 3. Gambaran mikroskopis massa tumor menunjukkan sel tumor yang berasal dari epitel gepeng yang masih berdiferensiasi.

Pasien datang dengan keadaan umum sedang dan kesadaran compos mentis cooperative, tekanan darah $120 / 70 \mathrm{mmHg}$, nadi $75 \mathrm{x} /$ menit, nafas $20 \mathrm{x} /$ menit, suhu $37^{\circ} \mathrm{C}$. Pada pemeriksaan fisik umum, pemeriksaan paru, jantung, dan abdomen dalam batas normal. Di regio inguinal kanan tampak tukak berjumlah tiga buah, ukuran $1 \times 0,5 \times 0,5 \mathrm{~cm}$ dan bernanah. Teraba massa berukuran $4 \times 3 \times 2 \mathrm{~cm}$, konsistensi kenyal padat, batas tegas, permukaan rata, terfiksasi, tidak ada nyeri tekan. Pada pemeriksaan alat kelamin, tampak penis sudah diangkat, teraba massa di skrotum kanan ukuran $4 \times 2 \times 1,5$ $\mathrm{cm}$ dengan perabaan kenyal padat, permukaan rata, batas tegas dan tidak nyeri tekan. Dari hasil pemeriksaan laboratorium didapatkan kadar hemoglobin $11,5 \mathrm{~g} / \mathrm{dL}$, leukosit $8.400 / \mathrm{mm}^{3}$, hematokrit $35 \%$, trombosit 212.000/ $\mathrm{mm}^{3}$, LED $57 \mathrm{~mm} / \mathrm{jam}$, hitung jenis leukosit 0/2/0/85/12/1. Fungsi ginjal, hepar dan elektrolit dalam batas normal. Hasil pemeriksaan urine dan feses dalam batas normal.

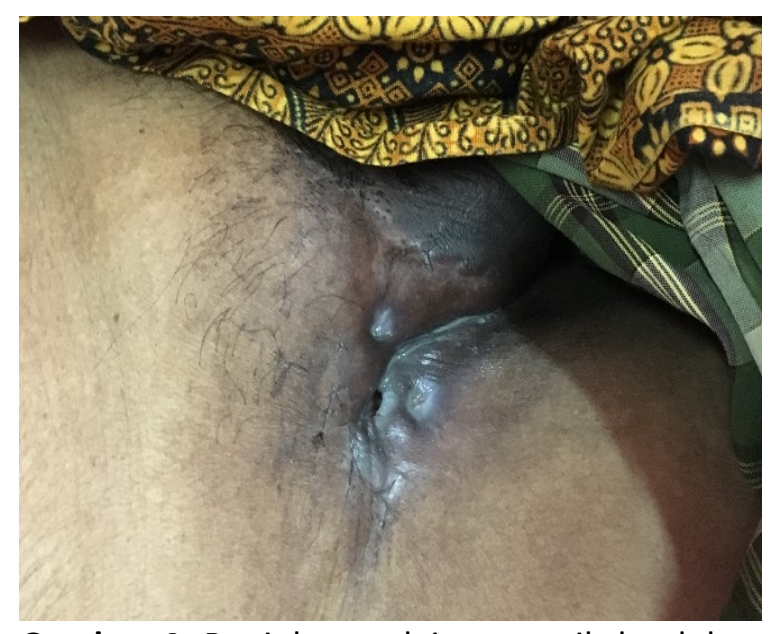

Gambar 4. Benjolan mulai mengecil dan luka mengering setelah kemoterapi kedua

Pada pasien dilakukan rontgen torak PA dengan hasil dalam batas normal dan tidak ditemukan metastasis. CT Scan Abdomen dengan kontras menunjukkan adanya massa berdensitas hipodens inhomogen di daerah inguinal kanan dengan batas tepi

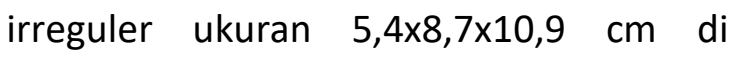
inguinal kanan meluas sampai ke skrotum kanan dan kiri, tak tampak kalsifikasi. Diagnosis pasien ini ditegakkan dengan 
Squamous Cell Carcinoma Penis Stadium IV (TxN3M0) post total penectomy dan perineostomy. Echocardiography menunjukkan fungsi sistolik global LV baik dengan EF 60\%. Untuk tatalaksana pasien saat ini adalah pemberian kemoterapi sesuai guideline NCCN.

Kemoterapi dilakukan dengan regimen Cisplatin dan 5-Fluorouracil (5-FU). Kemoterapi dilakukan berkelanjutan selama 5 hari, di mana Cisplatin diberikan hanya pada hari pertama dengan dosis 100 $\mathrm{mg} / \mathrm{m}^{2}$ (170mg). Sedangkan drip 5-FU diberikan dengan dosis $500 \mathrm{mg} / 500 \mathrm{cc}$ $\mathrm{NaCl}$ 0,9\% sebanyak $3 x$ dilanjutkan dengan 200 mg/500 cc NaCl 0,9\%. Sebagai premedikasi diberikan injeksi Diphenhidramin 1 ampul, Ondansetron 16 $\mathrm{mg}$, Ranitidine $50 \mathrm{mg}$, dan Dexamethasone 2 ampul secara intravena. Untuk pemenuhan kebutuhan gizi diberikan juga suplementasi vitamin B kompleks, vitamin C dan zink pada pasien. Selama perawatan, kondisi pasien stabil, terdapat efek kemoterapi berupa mual namun masih dapat diatasi dengan pemberian Ondansetron. Pasien menunjukkan respon terhadap kemoterapi, yang tampak dari ukuran benjolan yang mengecil setelah kemoterapi. Pada akhir siklus kemoterapi kedua, ukuran benjolan di regio inguinal kanan menjadi $3 \times 2 \times 1,5 \mathrm{~cm}$.

\section{PEMBAHASAN}

Telah dilaporkan seorang pasien laki-laki usia 58 tahun yang dirawat di Bangsal Penyakit Dalam RSUP dr. M. Djamil dengan diagnosis Squamous Cell Carcinoma Penis
Stadium IV (TxN3M0) post total penectomy dan perineostomy.

Karsinoma penis adalah keganasan yang jarang di seluruh dunia. Insidennya hanya mewakili 0,4-0,6\% dari semua keganasan pada pria di Amerika Serikat dan Eropa. ${ }^{1}$ Dari penggalian faktor risiko pada pasien ini, tidak ditemukan tanda infeksi virus HPV seperti riwayat kutil pada penis. Namun pasien merupakan perokok berat, di mana merokok bisa meningkatkan insiden hingga 4,5 kali lipat. $^{2}$

Pasien di-sirkumsisi pada usia 12 tahun, usia yang masih membantu mencegah insiden keganasan pada penis. Namun bukti yang lebih kuat menunjukkan efek proteksi karsinoma penis pada laki-laki yang di-sirkumsisi saat masih bayi. ${ }^{1}$ Faktor lainnya yang mendukung pada pasien ini adalah usia di atas 50 tahun dan status sosio-ekonomi yang rendah. ${ }^{3}$

Hasil pemeriksaan patologi anatomi dari jaringan tumor pada pasien menunjukkan adanya sel kanker yang berasal dari epitel gepeng yang masih berdiferensiasi dengan baik. Namun walau bukan sel high grade, sel kanker tersebut telah menginfiltrasi jaringan ikat di dekatnya serta ukuran tumor saat itu mencapai $10 \mathrm{~cm}$ sehingga menjadi indikasi untuk dilakukannya amputasi penis atau penectomy. Merujuk dari guideline kanker penis yang dikeluarkan oleh National Comprehensive Cancer Network (NCCN), tumor primer T2 atau lebih tanpa adanya kelenjar getah bening inguinal yang teraba harus dilakukan stratifikasi risiko penyebaran ke kelenjar getah bening inguinal-nya dengan 
CT Scan atau MRI abdomen/pelvis. ${ }^{2}$ Pada pasien saat itu telah dilakukan MRI Abdominopelvis dan tidak ditemukan adanya penyebaran.

Pada pasien ini akhirnya muncul benjolan di regio inguinal kanan yang semakin besar dan terfiksasi 6 bulan setelah penectomy. Pemeriksaan dilanjutkan dengan CT Scan Abdomen dengan kontras dan ditemukan massa di inguinal hingga skrotum. Adanya penyebaran tersebut menempatkan penyakit pasien pada stadium IV dengan staging nodul limfa N3, serta metastasis jauh MO karena tidak ditemukan penyebaran sel kanker di lokasi lain dari pemeriksaan klinis dan penunjang.

Squamous Cell Carcinoma penis memiliki pola metastasis yang dapat diprediksi, di mana yang pertama muncul adalah kelenjar getah bening regional, diikuti kelenjar getah bening bagian dalam baru kemudian metastasis jauh., ${ }^{9,10}$ Otak, paru, hepar, dan tulang adalah lokasi-lokasi yang khas untuk terjadinya metastasis jauh. ${ }^{11,12}$

Karsinoma penis stadium IV diterapi dengan kemoterapi. ${ }^{2}$ Pilihan regimen kemoterapi lini pertama pada keadaan ini adalah regimen Cisplatin-based, yang meliputi Paclitaxel, Ifosfamide, dan Cisplatin, atau alternatif lain adalah 5-FU dan Cisplatin. 5-FU dan Cisplatin diberikan dengan infus kontinu 5-FU 800-1000 $\mathrm{mg} / \mathrm{m}^{2} / \mathrm{hari}$ intravena pada hari 1-4 atau hari 2-5.13,14 Dengan Cisplatin diberikan secara IV pada hari ke-1 $100 \mathrm{mg} / \mathrm{m}^{2}$. Siklus diulang setiap 3-4 minggu. Pasien ini telah selesai menjalani kemoterapi dengan regimen 5-FU dan Cisplatin sebanyak dua siklus. ${ }^{15,16}$

Hal lain yang perlu diperhatikan dalam tatalaksana pasien ini adalah kualitas hidup, di mana kanker penis dan pengobatannya dapat secara serius mempengaruhi seksualitas dan intimasi, citra tubuh, fungsi berkemih, kesehatan mental dan health-related quality of life (HRQOL). ${ }^{17,18}$ Belum banyak penelitian yang mengkaji masalah ini, dari sebuah systematic review didapatkan kesimpulan bahwa pengobatan kanker penis secara negatif mempengaruhi kesejahteraan pasien hingga $40 \%$, dengan penurunan fungsi seksual hingga $60 \%{ }^{19}$

Dalam fungsi berkemih, dilaporkan adanya keluhan kebocoran akibat rendahnya pancaran urine (35\%) dan penis yang terlalu pendek (35\%). Sedangkan sekitar $25 \%$ melaporkan harus duduk saat berkemih karena perineal urethrostomy, seperti yang dialami oleh pasien ini. ${ }^{20}$

\section{SIMPULAN}

Pilihan terapi pasien dengan diagnosis Squamous Cell Carcinoma Penis Stadium IV (TxN3M0) adalah kemoterapi. Pasien ini telah dilakukan dua siklus kemoterapi dengan interval 3 minggu dan hasil menunjukkan adanya respon dimana ukuran benjolan mulai mengecil. 


\section{DAFTAR PUSTAKA}

1. Hakenberg OW, Compérat E, Minhas S, Necchi A, Protzel C, Watkin N. EAU Guideline on Penile Cancer. European Association of Urology. 2014; p.13-17.

2. Lughezzani G, Catanzaro M, Torelli T, Piva L, Biasoni D, Stagni S, et al. The relationship between characteristics of inguinal lymph nodes and pelvic lymph node involvement in penile squamous cell carcinoma: a single institution experience. J Urol. 2014; 191(4):977-82. doi: 10.1016/i.juro.2013.10.140. [PubMed]

3. Hakenberg OW, Compérat E, Minhas S, Necchi A, Protzel C, Watkin N. EAU Guidelines on Penile Cancer: 2014 Update. European Association of Urology. 2015; p.142-50.

4. Ottenhof SR, Bleeker M, Heideman D, Snijders P, Meijer C, Horenblas S. Epidemiology of Penile Cancer. In: Muneer A, Horenblas S, editors. Textbook of Penile Cancer. Cham: Springer; 2016. p.105-10. doi: 10.1007/978-3-319-33220-8.

5. Marchionne E, Perez C, Hui A, Khachemoune A. Penile squamous cell carcinoma: a review of the literature and case report treated with Mohs micrographic surgery. An Bras Dermatol. 2017; 92(1):95-99. doi: 10.1590/abd1806-4841.20175009. [PubMed].

6. Prayoga DA, Tranggono U. Evaluasi Klinis dan Manajemen Kanker Penis di Rumah Sakit Sardjito, Yogyakarta. Indonesian Journal of Cancer. 2016; 10(1):29-34. doi: 10.33371/ijoc.v10i1.411.

7. Sharma $P$, Zargar-Shoshtari K, Pettaway $C A$, Schabath $M B$, Giuliano AR, Spiess PE. Disparities in penile cancer. Cancer Control. 2016; 23(4):409-14. doi: 10.1177/107327481602300412.

8. Brady KL, Mercurio MG, Brown MD. Malignant tumors of the penis. Dermatol Surg. 2013; 39(4):527-47. doi: 10.1111/dsu.12029. [PubMed].

9. Compérat E. Pathology of Penile Cancer. Eur Urol Suppl. 2018; 17(6):132-7. doi: 10.1016/j.eursup.2017.08.005.

10. Hanchanale V, Yeo L, Subedi N, Smith J, Wah T, Harnden P, et al. The accuracy of magnetic resonance imaging (MRI) in predicting the invasion of the tunica albuginea and the urethra during the primary staging of penile cancer. BJU Int 2016; 117(3):439-43. doi: 10.1111/bju.13041. [PubMed]

11. Chipollini J, Tang DH, Gilbert SM, Poch MA, Sexton WJ, Spiess PE, et al. Delay to Inguinal Lymph Node Dissection Greater than 3 Months Predicts Poorer Recurrence-Free Survival for Patients with Penile Cancer. J Urol. 2017; 198(6):1346-1352. doi: 10.1016/j.juro.2017.06.076. [PubMed].

12. O'Brien JS, Perera M, Manning T, Bozin T, Cabarkapa S, Chen E, et al. Penile Cancer: Contemporary Lymph Node Management. J Urol. 2017 Jun;197(6):1387-1395. doi: 10.1016/j.juro.2017.01.059. [PubMed]

13. Brady KL, Scott GA, Gilmore ES. Cutaneous metastasis from penile squamous cell carcinoma resembling carcinoma en cuirasse. Dermatol Online J. 2014; 21(3). [PubMed].

14. Bansal H, Chaudhary A, Batra D, Jindal R. Metastasis from Penile Squamous Cell Carcinoma to Brain: A Case Report and Review of Literature. Indian Journal of Neurosurgery. 2018; 7(2):164-7. doi: $10.1055 / \mathrm{s}-0037-1601359$.

15. Fishmen MN. Clinical scenarios for neoadjuvant chemotherapy for squamous penile cancer that is clinically node positive. Transl Androl Urol. 2017; 6(5):839-847. doi: 10.21037/tau.2017.08.02. [PubMed]. 
16. McCormick B, Pettaway C. Insights Into the Management of Lymph Node-Positive Penile Cancer. JAMA Oncol. 2018; 4(5):650-651. doi: 10.1001/jamaoncol.2017.5634. [PubMed]

17. Leone A, Diorio GJ, Pettaway C, Master V, Spiess PE. Contemporary management of patients with penile cancer and lymph node metastasis. Nat Rev Urol. 2017; 14(6):335-347. doi: 10.1038/nrurol.2017.47. [PubMed].

18. Kieffer JM, Djajadiningrat RS, van Muilekom EA, Graafland NM, Horenblas S, Aaronson NK. Quality of life in patients treated for penile cancer. J Urol. 2014; 192(4):1105-10. doi: 10.1016/j.juro.2014.04.014. [PubMed].

19. Sansalone S, Silvani M, Leonardi R, Vespasiani G, Lacovelli V. Sexual outcomes after partial penectomy for penile cancer: results from a multi-institutional study. Asian J Androl. 2017; 19(1):57-61. doi: 10.4103/1008-682X.168690. [PubMed].

20. Simpson WG, Klaassen Z, Jen RP, Hughes WM 5th, Neal DE Jr, Terris MK. Analysis of Suicide Risk in Patients with Penile Cancer and Review of the Literature. Clin Genitourin Cancer. 2018; 16(2):e257-e261. doi: 10.1016/j.clgc.2017.09.011. [PubMed]. 